\title{
Midtropospheric Circulation Patterns Associated with Extreme Dry and Wet Episodes over Equatorial Eastern Africa during the Northern Hemisphere Spring
}

\author{
RAPHAEL E. OKOOLA \\ Department of Meteorology, University of Nairobi, Nairobi, Kenya
}

(Manuscript received 4 March 1998, in final form 5 September 1998)

ABSTRACT

\begin{abstract}
The anomaly circulation patterns of contrasting wet and dry episodes over the equatorial eastern Africa (EEA) region are studied using the European Centre for Medium-Range Weather Forecasts analyses. The study focuses on the Northern Hemisphere spring (NHS). Examination of composite synoptic-scale features indicates that cyclonic circulation over southern Madagascar in the midtroposphere forces southerly flow through the Mozambique Channel. The southerlies turn eastward on approaching latitude $10^{\circ} \mathrm{S}$ giving broad westerlies in the latitude belt $10^{\circ} \mathrm{S}$ to the equator. These southerlies followed by westerlies were associated with wet spells over the EEA region. Dry spells exhibit stronger than normal easterly wind flow over the EEA region. These dry spells are associated with a cyclonic circulation with a center near the point $25^{\circ} \mathrm{S}, 25^{\circ} \mathrm{E}$ and an anticyclonic circulation over Madagascar that causes northerly winds to blow through the Mozambique Channel. Thus, the southerlies act as a trigger for active convection over EEA during the NHS by providing a surface leaning poleward with height over which the equatorial air mass rises.
\end{abstract}

\section{Introduction}

In the Tropics the most important climate element is rainfall. Rainfall determines the economies of most tropical countries. Rainy seasons alternate with dry seasons and each has its distinct pattern of prevailing winds (Matarira and Jury 1992; Nakamura 1968; Johnson and Morth 1961). Rainfall has the highest space-time variability. Matarira and Jury (1992) have shown that the meridional wind was generally southerly over and to the east of Zimbabwe at the 700-hPa level during the dry spells, whereas it was northerly during the wet spells. The meridional flow during the dry spells suggests that convergence between the southerlies and the moist Congo Basin northerlies occurs well to the north of Zimbabwe. Nakamura (1968) and Johnson and Morth (1961) have shown that midtropospheric westerly winds over equatorial eastern Africa (EEA) were associated with transport of moisture into the region. However, they did not suggest the origin of these westerlies. The above research results suggest that both meridional and zonal winds may be important for the occurrence of anomalous rains over the EEA region.

The location of the intertropical convergence zone (ITCZ) and its overall horizontal and vertical structure

Corresponding author address: Dr. R. E. Okoola, University of Nairobi, Department of Meteorology, P.O. Box 30197, Nairobi, Kenya

E-mail: raphael.okoola@lion.meteo.go.ke influence the space-time patterns of rainfall in the EEA region. Although there is some descriptive information on the characteristics of the ITCZ, there are no available quantitative descriptions of the space-time evolution of ITCZ over this region. Characteristics of the ITCZ over the region are complicated by the topographic inhomogeneity and the associated thermally induced mesoscale circulations that make the ITCZ patterns near the earth's surface very diffused (Mukabana and Pielke 1996). However, the ITCZ has been observed most clearly in the wind field near $700 \mathrm{hPa}$ level (Anyamba 1983; Mukabana and Pielke 1996). Thus, accurate assessment of the circulation regimes that support various rainfall patterns over this region may be based on circulation patterns at the $700-\mathrm{hPa}$ level.

The prediction of wet or dry seasons is useful for agricultural and water resource use planning. However, the monitoring of crop yield requires a shorter event scale since it is often not the amount of seasonal rainfall that is important, but rather the steadiness of rainfall supplied by repeated wet or dry spells that is crucial to high crop yields. Thus, in order to construct a scenario for wet-spell forecasting, a diagnostic study of the wet spell is necessary. This paper addresses this problem through analysis of wind patterns over EEA region composited over periods characterized by wet and dry pentad (five-day totals) rainfall cases in EEA. The objective of the study is to identify the vector wind patterns and intensity associated with these wet and dry cases. 


\section{Data used in the study}

The data used in this study include daily and monthly station rainfall totals and the European Centre for Medium-Range Weather Forecasts (ECMWF) global analyses datasets.

The rainfall data consists of daily and monthly records at 81 stations distributed over eastern Africa within the period 1961-90 (Fig. 1 and Table 1). The Northern Hemisphere spring (NHS), that is, March, April, and May monthly records, the long rains season over eastern Africa, were used to generate the NHS regional time series for 1961-90 from which the anomalously wet and dry years were delineated. The monthly rainfall totals used were obtained from the individual National Meteorological Services of Kenya, Uganda, and Tanzania through the Drought Monitoring Centre, Nairobi. The daily rainfall data for the selected anomalous wet and dry years were supplied by Kenya and Tanzania Meteorological Services (those for Uganda were not available). These daily records were used to generate pentad records that were used to delineate the wet and dry clusters within the selected years for further study.

This study also utilized the once-daily (1200 UTC) gridpoint meteorological variables operationally analyzed by the ECMWF. These ECMWF analyses are produced using the four-dimensional data assimilation system (Bengtsson et al. 1982). The spatial resolution is $2.5^{\circ}$ latitude by $2.5^{\circ}$ longitude for the mid- and lowlatitude sector $25^{\circ} \mathrm{N}-45^{\circ} \mathrm{S}$ and between longitudes $30^{\circ} \mathrm{W}$ and $85^{\circ} \mathrm{E}$. These data were for the anomalous rainfall years that were determined from seasonal rainfall data.

The 1200 UTC daily data were averaged to make pentad mean values. These data included the zonal and meridional wind components. The ECMWF datasets used in this study were obtained through the Bureau of Meteorology Research Centre, Australia.

\section{Methodology}

\section{a. Determination of anomalous rainfall years}

The major wet and dry years within the study period (1961-90) were determined from the regional rainfall anomaly indices. The regional rainfall anomaly indices are defined as

$$
\chi_{t}=\frac{1}{m} \sum_{j=1}^{m} \frac{100 X_{t j}}{\bar{X}_{j}},
$$

where $m$ is the total number of rainfall stations within the EEA region and $\chi_{t}$ is the time-dependent rainfall index as a percent of the mean and averaged over all the stations used.

The wet years had large values of this index $(>125 \%)$, while the drought years had low values of the index $(<75 \%)$. The normal years had values of this index between $125 \%$ and $75 \%$. The major wet and dry seasons were first delineated. Then the averaged values (composites) for each anomaly category were used to study the space-time evolutions of the monsoonal circulation over the region during the anomalous rainfall episodes.

\section{b. Principal component analysis}

To confirm the results from Eq. (1) above, principal component analysis (PCA) was used to select rainfall events to be composed. These PCA solutions can be used to cluster together seasons or pentads with similar map patterns. Through this method rainfall records were subjected to PCA T-mode for the seasonal (March-May) rainfall. The loadings from this analysis were classified into three categories, namely, normal, large positive, and negative values. The delineated years were compared with those that had been obtained from area-average rainfall anomaly indices given in Eq. (1).

The pentad rainfall values for the anomalous years and for various locations over EEA were subjected to PCA T-mode analysis. The pentads so delineated were then used to study the detailed characteristics of the dry, normal, and wet scenarios. This included a detailed study of the wet and dry spells within the selected anomalous rainfall years.

\section{c. Composite analysis}

The composite analysis involves identifying and averaging one or more categories of fields of a variable selected according to their association with key conditions (Folland 1983). The results of these composites are then used to generate hypotheses for patterns that may be associated with the individual scenarios (Folland 1983). The key conditions for the composite analysis in the present study are the wet, normal, and drought conditions defined in section $3 \mathrm{a}$ above. Advantages of composite fields is that they are easy to interpret and are dimensional. A number of studies have indicated that the results obtained from composite analysis usually agree closely with those from correlation methods (Ward 1992).

In this study the anomalously wet and dry years selected using methods in section $3 \mathrm{a}$ above were composed in order to isolate the circulation patterns associated with the wet and dry seasons. Also, the individual selected wet/dry seasons were further expressed in pentads and these were analyzed to delineate wet and dry rainfall spells that were then composed to identify the within-the-season wet- and dry-spell circulation patterns.

\section{Results and discussion}

\section{a. The dry and wet periods}

Equation (1) was used to identify the seasonal values of rainfall anomaly indices. The dry/wet seasons were associated with low/high values of this index, 


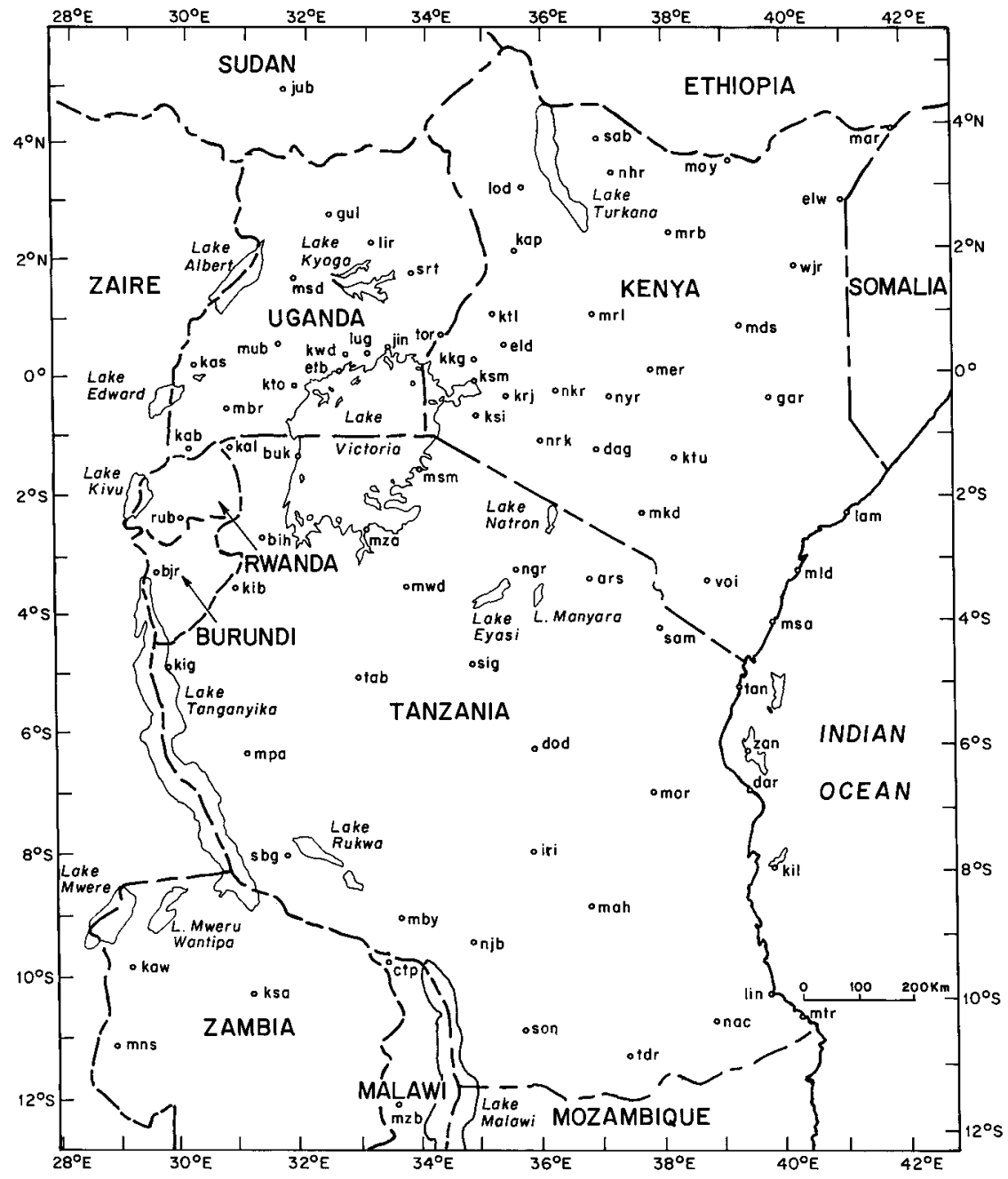

FIG. 1. Location of rainfall stations in the study region (see also Table 1).

respectively. The time series of the computed values of the area-average rainfall indices are presented in Fig. 2. These indices showed that the wettest/driest years over the EEA region were 1981/1984, respectively. Okoola (1998) using the March-May seasonal outgoing longwave radiation (OLR) data averaged over the eastern Africa region has also shown that 1981/1984 were active/weak convective years. Further, LeComte (1985) has shown that during the northern hemisphere spring (March-June) of 1984 one of the worst droughts of the century damaged food crops in East Africa. These wet/dry years were used in the composite analysis.

Due to the nonhomogeneous distribution of rainfall observational network and unique spatial rainfall variations over the region, PCA T-mode was further used to provide area-average rainfall estimates. The PCA T-mode isolated the years with similar spatial patterns. This method provides further individual time series for unique homogeneous climatological subregions unlike the previous method, which provided a single time series for the whole region. Three significant eigenvectors were delineated and these accounted for $78 \%$ of total variance. The time series of rotated PCA T-mode analysis had large loadings during the years 1981, 1985, 1988, and 1990 and low loadings in 1979, 1982, 1983, 1984, and 1986, respectively. These large/low loadings were associated with anomalously wet/dry years over the EEA region. Through this method the years 1981/1984 were also selected as wet/dry years.

The wet and dry pentads during each of the selected years (1981 and 1984) were delineated using the PCA T-mode analysis of the seasonal rainfall series running from pentad 10 (15-19 February) to pentad 32 (5-9 June). Six wet pentads (pentads 18-21 and 26-27) occurred in 1981 and three wet pentads (pentads 2022) occurred in 1984. One dry pentad (pentad 25) 
TABLE 1. Location of rainfall stations and their elevations above mean sea level where monthly rainfall data were available and starred $\left.{ }^{*}\right)$ where daily rainfall data were also available.

\begin{tabular}{|c|c|c|c|c|c|}
\hline $\begin{array}{c}\text { Country and } \\
\text { stations }\end{array}$ & $\begin{array}{l}\text { Station code } \\
\text { name }\end{array}$ & Latitude & Longitude & $\begin{array}{l}\text { Elevation } \\
(\mathrm{m})\end{array}$ & $\begin{array}{l}\text { Length of } \\
\text { record }\end{array}$ \\
\hline \multicolumn{6}{|l|}{ BURUNDI } \\
\hline Bujumbura & *bjr & $3^{\circ} 19^{\prime} \mathrm{N}$ & $29^{\circ} 19^{\prime}$ & 782 & 1961-89 \\
\hline \multicolumn{6}{|l|}{ KENYA } \\
\hline Dagoretti & $*$ dag & $1^{\circ} 18^{\prime} \mathrm{S}$ & $36^{\circ} 45^{\prime}$ & 1798 & 1961-92 \\
\hline Eldoret & *eld & $0^{\circ} 31^{\prime} \mathrm{N}$ & $35^{\circ} 17^{\prime}$ & 2084 & 1967-92 \\
\hline El Wak & elw & $2^{\circ} 47^{\prime} \mathrm{N}$ & $40^{\circ} 57^{\prime}$ & 394 & $1961-92$ \\
\hline Garissa & *gar & $0^{\circ} 28^{\prime} \mathrm{S}$ & $39^{\circ} 38^{\prime}$ & 128 & 1967-92 \\
\hline Kakamega & $* k k g$ & $0^{\circ} 17^{\prime} \mathrm{N}$ & $34^{\circ} 45^{\prime}$ & 1555 & 1961-92 \\
\hline Kaputir & Kap & $2^{\circ} 6^{\prime} \mathrm{N}$ & $35^{\circ} 28^{\prime}$ & 754 & $1971-92$ \\
\hline Kericho & $* \mathrm{Krj}$ & $0^{\circ} 29^{\prime}$ & $35^{\circ} 11^{\prime}$ & 2184 & 1961-92 \\
\hline Kisii & $* \mathrm{Ksi}$ & $0^{\circ} 41^{\prime} \mathrm{S}$ & $34^{\circ} 47^{\prime}$ & 1837 & 1963-92 \\
\hline Kisumu & $* \mathrm{Ksm}$ & $0^{\circ} 6^{\prime} \mathrm{S}$ & $34^{\circ} 45^{\prime}$ & 1146 & 1961-92 \\
\hline Kitale & $* \mathrm{Ktl}$ & $1^{\circ} 1^{\prime} \mathrm{N}$ & $35^{\circ} 0^{\prime}$ & 1890 & 1961-92 \\
\hline Kitui & Ktu & $1^{\circ} 22^{\prime} \mathrm{S}$ & $38^{\circ} 1^{\prime}$ & 1177 & $1961-92$ \\
\hline Lamu & *Lam & $2^{\circ} 16^{\prime} \mathrm{S}$ & $40^{\circ} 50^{\prime}$ & 9 & 1961-92 \\
\hline Lodwar & $*$ Lod & $3^{\circ} 7^{\prime} \mathrm{N}$ & $35^{\circ} 37^{\prime}$ & 566 & $1961-92$ \\
\hline Makindu & $* \mathrm{Mkd}$ & $2^{\circ} 17^{\prime} \mathrm{S}$ & $37^{\circ} 50^{\prime}$ & 1000 & $1961-92$ \\
\hline Malindi & *Mld & $3^{\circ} 14^{\prime} \mathrm{S}$ & $40^{\circ} 6^{\prime}$ & 3 & $1962-92$ \\
\hline Mandera & $* \mathrm{Mdr}$ & $3^{\circ} 56^{\prime} \mathrm{N}$ & $41^{\circ} 52^{\prime}$ & 230 & $1961-92$ \\
\hline Maralal & Mrl & $1^{\circ} 5^{\prime} \mathrm{S}$ & $36^{\circ} 42^{\prime}$ & 1951 & 1961-92 \\
\hline Marsabit & $* \mathrm{Mrb}$ & $2^{\circ} 18^{\prime} \mathrm{N}$ & $37^{\circ} 54^{\prime}$ & 1219 & $1961-92$ \\
\hline Meru & $*$ Mer & $0^{\circ} 3^{\prime} \mathrm{N}$ & $37^{\circ} 39^{\prime}$ & 1570 & 1966-92 \\
\hline Mombasa & $*$ Msa & $4^{\circ} 2^{\prime} \mathrm{S}$ & $39^{\circ} 37^{\prime}$ & 57 & $1961-92$ \\
\hline Moyale & *Moy & $3^{\circ} 32^{\prime} \mathrm{N}$ & $39^{\circ} 3^{\prime}$ & 1113 & $1961-92$ \\
\hline Mudogashi & Mds & $0^{\circ} 45^{\prime} \mathrm{N}$ & $39^{\circ} 11^{\prime}$ & 262 & $1964-92$ \\
\hline Nakuru & $* \mathrm{Nkr}$ & $0^{\circ} 17^{\prime} \mathrm{S}$ & $36^{\circ} 4^{\prime}$ & 1991 & $1961-92$ \\
\hline Narok & $* N r k$ & $1^{\circ} 8^{\prime} \mathrm{S}$ & $35^{\circ} 50^{\prime}$ & 1890 & $1961-92$ \\
\hline North Horr & Nhr & $3^{\circ} 19^{\prime} \mathrm{N}$ & $37^{\circ} 4^{\prime}$ & & $1961-92$ \\
\hline Nyeri & Nyr & $0^{\circ} 30^{\prime} \mathrm{S}$ & $36^{\circ} 58^{\prime}$ & 1759 & $1961-92$ \\
\hline Saberei & $\mathrm{Sab}$ & $4^{\circ} 21^{\prime} \mathrm{N}$ & $36^{\circ} 54^{\prime}$ & 250 & $1962-92$ \\
\hline Voi & *Voi & $3^{\circ} 24^{\prime} \mathrm{S}$ & $38^{\circ} 34^{\prime}$ & 579 & $1961-92$ \\
\hline Wajir & *Wjr & $1^{\circ} 45^{\prime} \mathrm{N}$ & $40^{\circ} 4^{\prime}$ & 244 & 1961-92 \\
\hline \multicolumn{6}{|l|}{ RWANDA } \\
\hline Rubona & $*$ Rub & $2^{\circ} 27^{\prime} \mathrm{S}$ & $29^{\circ} 44^{\prime}$ & 1706 & $1961-90$ \\
\hline \multicolumn{6}{|l|}{ TANZANIA } \\
\hline Arusha & $*$ Ars & $3^{\circ} 20^{\prime} \mathrm{S}$ & $36^{\circ} 37^{\prime}$ & 1387 & $1961-90$ \\
\hline Biharamulo & Bih & $2^{\circ} 38^{\prime} \mathrm{S}$ & $31^{\circ} 19^{\prime}$ & 1478 & $1961-90$ \\
\hline Bukoba & $*$ Buk & $1^{\circ} 20^{\prime} \mathrm{S}$ & $31^{\circ} 49^{\prime}$ & 1143 & $1961-90$ \\
\hline Dar-es-Salaam & $*$ Dar & $6^{\circ} 52^{\prime} \mathrm{S}$ & $39^{\circ} 12^{\prime}$ & 53 & $1961-90$ \\
\hline Dodoma & *Dod & $6^{\circ} 10^{\prime} \mathrm{S}$ & $35^{\circ} 46^{\prime}$ & 1120 & $1961-90$ \\
\hline Iringa & $*$ Iri & $7^{\circ} 38^{\prime} \mathrm{S}$ & $35^{\circ} 46^{\prime}$ & 1428 & $1961-90$ \\
\hline Kaisho & Kai & $1^{\circ} 15^{\prime} \mathrm{S}$ & $30^{\circ} 41^{\prime}$ & 1372 & $1961-90$ \\
\hline Kibondo & Kib & $3^{\circ} 34^{\prime} \mathrm{S}$ & $30^{\circ} 40^{\prime}$ & 1515 & $1961-90$ \\
\hline Kigoma & $* \mathrm{Kig}$ & $4^{\circ} 53^{\prime} \mathrm{S}$ & $29^{\circ} 38^{\prime}$ & 999 & $1961-90$ \\
\hline Kilindoni & Kil & $7^{\circ} 55^{\prime} \mathrm{S}$ & $39^{\circ} 40^{\prime}$ & 21 & $1961-90$ \\
\hline Lindi & Lin & $10^{\circ} 0^{\prime} \mathrm{S}$ & $39^{\circ} 42^{\prime}$ & 41 & $1961-90$ \\
\hline Lupatingatinga & Lup & $7^{\circ} 40^{\prime} \mathrm{S}$ & $33^{\circ} 25^{\prime}$ & 1524 & $1961-90$ \\
\hline Mahenge & Mah & $8^{\circ} 41^{\prime} \mathrm{S}$ & $36^{\circ} 43^{\prime}$ & 1106 & $1961-90$ \\
\hline Mbeya & *Mby & $8^{\circ} 56^{\prime} \mathrm{S}$ & $33^{\circ} 28^{\prime}$ & 1758 & $1961-90$ \\
\hline Morogoro & Mor & $6^{\circ} 50^{\prime} \mathrm{S}$ & $37^{\circ} 39^{\prime}$ & 579 & $1961-90$ \\
\hline Mpanda & Мpa & $6^{\circ} 20^{\prime} \mathrm{S}$ & $31^{\circ} 5^{\prime}$ & 1097 & $1961-90$ \\
\hline Musoma & *Msm & $1^{\circ} 30^{\prime} \mathrm{S}$ & $33^{\circ} 48^{\prime}$ & 1147 & $1961-90$ \\
\hline Mtwara & $*$ Mtr & $10^{\circ} 21^{\prime} \mathrm{S}$ & $40^{\circ} 11^{\prime}$ & 113 & $1961-90$ \\
\hline Mwadui & Mwd & $3^{\circ} 31^{\prime} \mathrm{S}$ & $33^{\circ} 36^{\prime}$ & 1219 & $1961-90$ \\
\hline Mwanza & $* \mathrm{Mza}$ & $2^{\circ} 28^{\prime} \mathrm{S}$ & $32^{\circ} 55^{\prime}$ & 1139 & $1961-90$ \\
\hline Nachingwea & $\mathrm{Nac}$ & $10^{\circ} 21^{\prime} \mathrm{S}$ & $38^{\circ} 45^{\prime}$ & 463 & $1961-90$ \\
\hline Ngoro̊ngoro & $\mathrm{Ngr}$ & $3^{\circ} 12^{\prime} \mathrm{S}$ & $35^{\circ} 27^{\prime}$ & 2288 & $1961-90$ \\
\hline Njombe & $\mathrm{Njb}$ & $9^{\circ} 20^{\prime} \mathrm{S}$ & $34^{\circ} 46^{\prime}$ & 1829 & $1961-90$ \\
\hline Same & *Sam & $5^{\circ} 5^{\prime} \mathrm{S}$ & $37^{\circ} 43^{\prime}$ & 860 & $1961-90$ \\
\hline Singida & Sig & $4^{\circ} 48^{\prime} \mathrm{S}$ & $34^{\circ} 45^{\prime}$ & 1498 & $1961-90$ \\
\hline Songea & *Son & $10^{\circ} 41^{\prime} \mathrm{S}$ & $35^{\circ} 35^{\prime}$ & 1036 & $1961-90$ \\
\hline Sumbawanga & Sbg & $7^{\circ} 57^{\prime} \mathrm{S}$ & $31^{\circ} 36^{\prime}$ & 1722 & $1961-90$ \\
\hline Tabora & $* \mathrm{Tab}$ & $5^{\circ} 5^{\prime} \mathrm{S}$ & $32^{\circ} 50^{\prime}$ & 1182 & $1961-90$ \\
\hline
\end{tabular}


TABLE 1. (Continued).

\begin{tabular}{|c|c|c|c|c|c|}
\hline $\begin{array}{c}\text { Country and } \\
\text { stations }\end{array}$ & $\begin{array}{c}\text { Station code } \\
\text { name }\end{array}$ & Latitude & Longitude & $\begin{array}{l}\text { Elevation } \\
\text { (m) }\end{array}$ & $\begin{array}{l}\text { Length of } \\
\text { record }\end{array}$ \\
\hline Tanga & *Tan & $11^{\circ} 6^{\prime} \mathrm{S}$ & $39^{\circ} 4^{\prime}$ & 49 & 1961-90 \\
\hline Tunduru & $\mathrm{Tdr}$ & $6^{\circ} 13^{\prime} \mathrm{S}$ & $37^{\circ} 22^{\prime}$ & 701 & 1961-90 \\
\hline Zanzibar & Zan & $2^{\circ} 28^{\prime} \mathrm{S}$ & $39^{\circ} 13^{\prime}$ & 18 & $1961-90$ \\
\hline \multicolumn{6}{|l|}{ UGANDA } \\
\hline Entebbe & Etb & $0^{\circ} 3^{\prime} \mathrm{S}$ & $32^{\circ} 27^{\prime}$ & 1183 & 1961-92 \\
\hline Gulu & Gul & $2^{\circ} 45^{\prime} \mathrm{N}$ & $32^{\circ} 20^{\prime}$ & 1106 & 1961-91 \\
\hline Jinja & Jin & $0^{\circ} 27^{\prime} \mathrm{N}$ & $33^{\circ} 11^{\prime}$ & 1175 & 1961-92 \\
\hline Kabale & $\mathrm{Kab}$ & $1^{\circ} 15^{\prime} \mathrm{N}$ & $29^{\circ} 59^{\prime}$ & 1867 & $1961-91$ \\
\hline Kasese & Kas & $0^{\circ} 11^{\prime} \mathrm{N}$ & $30^{\circ} 6^{\prime}$ & 959 & 1961-92 \\
\hline Katigondo & Kto & $0^{\circ} 13^{\prime} \mathrm{S}$ & $31^{\circ} 44^{\prime}$ & 1311 & 1964-92 \\
\hline Kawanda & Kwd & $0^{\circ} 25^{\prime} \mathrm{N}$ & $32^{\circ} 32^{\prime}$ & 1196 & 1961-92 \\
\hline Lira & Lir & $2^{\circ} 15^{\prime} \mathrm{N}$ & $32^{\circ} 54^{\prime}$ & 1085 & 1961-91 \\
\hline Masindi & Msd & $1^{\circ} 41^{\prime} \mathrm{N}$ & $31^{\circ} 43^{\prime}$ & 1146 & 1961-91 \\
\hline Mbarara & $\mathrm{Mbr}$ & $0^{\circ} 37^{\prime} \mathrm{S}$ & $30^{\circ} 39^{\prime}$ & 1412 & $1961-91$ \\
\hline Mubende & Mub & $0^{\circ} 35^{\prime} \mathrm{N}$ & $31^{\circ} 22^{\prime}$ & 1553 & 1961-90 \\
\hline Soroti & Srt & $1^{\circ} 43^{\prime} \mathrm{N}$ & $33^{\circ} 37^{\prime}$ & 1127 & 1961-90 \\
\hline Tororo & Tor & $0^{\circ} 42^{\prime} \mathrm{N}$ & $34^{\circ} 10^{\prime}$ & 1226 & 1961-91 \\
\hline \multicolumn{6}{|l|}{ MALAWI } \\
\hline Chitipa & $*$ Ctp & $9^{\circ} 42^{\prime} \mathrm{S}$ & $33^{\circ} 16^{\prime}$ & 1278 & $1961-87$ \\
\hline Mzimba & $* \mathrm{Mzb}$ & $11^{\circ} 53^{\prime} \mathrm{S}$ & $33^{\circ} 37^{\prime}$ & 1349 & $1961-90$ \\
\hline \multicolumn{6}{|l|}{ ZAMBIA } \\
\hline Kasama & $* \mathrm{Ksa}$ & $10^{\circ} 13^{\prime} \mathrm{S}$ & $31^{\circ} 8^{\prime}$ & 1382 & 1961-90 \\
\hline Kawambwa & * Kaw & $9^{\circ} 48^{\prime} \mathrm{S}$ & $29^{\circ} 5^{\prime}$ & 1323 & 1961-90 \\
\hline Mansa & $* \mathrm{Mns}$ & $11^{\circ} 6^{\prime} S$ & $28^{\circ} 51^{\prime}$ & 1259 & 1961-90 \\
\hline \multicolumn{6}{|l|}{ SUDAN } \\
\hline Juba & Jub & $4^{\circ} 52^{\prime} \mathrm{N}$ & $31^{\circ} 36^{\prime}$ & 460 & $1961-87$ \\
\hline
\end{tabular}

occurred in 1981 and three dry pentads (pentads 2325 ) in 1984. More wet pentads occurred during the wet year and more dry pentads occurred in the dry year.

\section{b. Circulation patterns for the wet and dry rainfall composites}

Vector wind patterns for the wet year (1981) during the long rains season pentads (16-28) are shown in Fig. 3 at $700-\mathrm{hPa}$ level. Figure 3 shows relatively stronger easterlies along approximately latitude $4^{\circ} \mathrm{N}$ and also along latitude $14^{\circ} \mathrm{S}$ with weaker and variable flow in between. Maximum intensity of $3.7 \mathrm{~m} \mathrm{~s}^{-1}$ was observed near the point $5^{\circ} \mathrm{N}, 27^{\circ} \mathrm{E}$. A minimum in wind intensity is located at the point $5^{\circ} \mathrm{S}, 35^{\circ} \mathrm{E}$ within the region of

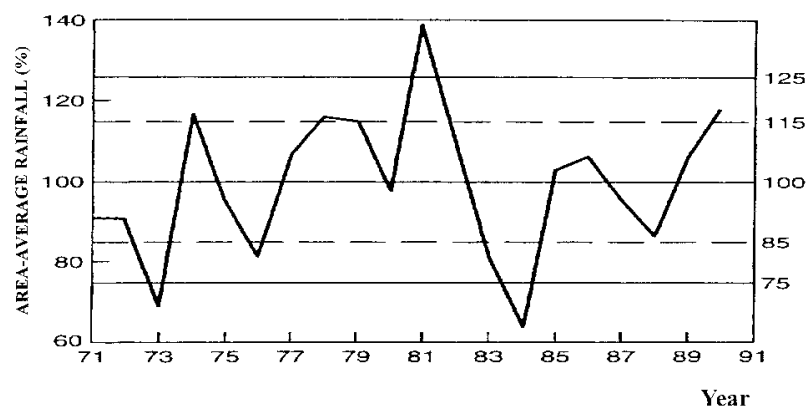

FIG. 2. Time series of area-average seasonal rainfall indices. study. A closed circulation is observed around this point of minimum wind intensity with westerlies to the south and relatively stronger easterlies to the north. To the east of the above minimum (east of $35^{\circ} \mathrm{E}$ ), and over the west Indian Ocean, southwesterly winds prevail, turning into easterlies near the equator. Figure 3 shows that generally westerly winds occurred between $10^{\circ} \mathrm{S}$ and the equator and to the east of $35^{\circ} \mathrm{E}$ during the wet season.

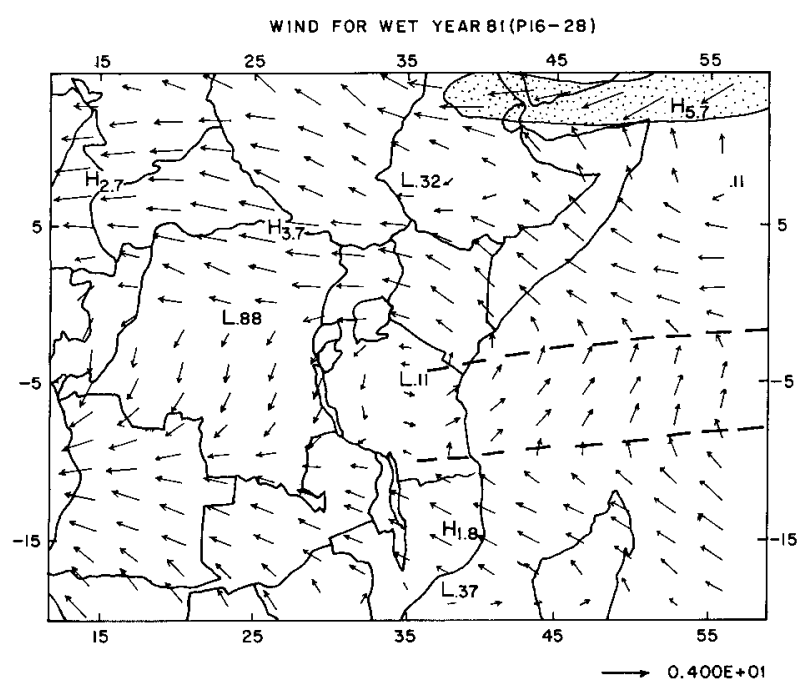

FIG. 3. Long rains season wind vectors at $700 \mathrm{hPa}$ during a wet year (1981). Shaded where wind is greater than $4 \mathrm{~m} \mathrm{~s}^{-1}$. 


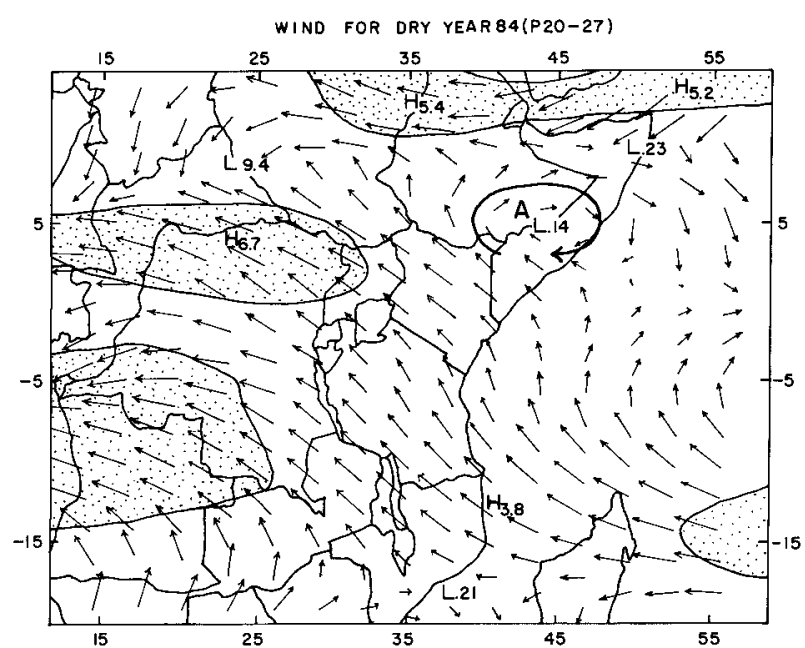

FIG. 4. Long rains season wind vectors at $700 \mathrm{hPa}$ during a dry year (1984). Shaded where wind is greater than $4 \mathrm{~m} \mathrm{~s}^{-1}$.

Okoola (1999) has shown, using latitude-time cross sections for the longitudes of eastern Africa, that during 1981 the frequency of westerly wind component was high, totalling six pentads from two westerly wind events.

The dry year (1984) composites at 700-hPa level (Fig. 4) shows that the wind intensity is, on average, stronger than normal. Maximum intensity of $6.7 \mathrm{~m} \mathrm{~s}^{-1}$ was observed near the point $4^{\circ} \mathrm{N}, 25^{\circ} \mathrm{E}$. Missing from the 1984 flow is the circulation centered at about $5^{\circ} \mathrm{S}, 35^{\circ} \mathrm{E}$ observed during the wet year (1981). Clearly the flow out of the EEA region was stronger than normal during the dry year (1984). Also, during the dry year a local anticyclonic circulation was observed in the winds near the point $5^{\circ} \mathrm{N}, 45^{\circ} \mathrm{E}$. This local anticyclonic circulation seems to be a feature of the dry years. Okoola (1999) has further shown from time-latitude sections that the frequency of westerly wind component was low with only three pentads (from one westerly wind event) during the 1984 long rains season. The fewer incidences of westerly winds resulted in the observed stronger easterly winds when compared to the wet case. Generally, Figs. 3 and 4 show that the midtropospheric wind intensity over the EEA region was relatively weak/strong during the wet/dry years.

The wind anomalies for the wet (1981) minus the dry (1984) were computed in order to show contrast between the two years (Fig. 5). Figure 5 at 700-hPa level depicts more clearly the spatial scale of the anomaly wind fields. A westerly wind anomaly over the region $10^{\circ} \mathrm{S}$ to the equator and from $20^{\circ}$ to $80^{\circ} \mathrm{E}$ can be seen. A significant feature of this anomalous midtropospheric flow was the cyclonic circulation observed to the south of Madagascar with the cyclonic center near the point $25^{\circ} \mathrm{S}, 50^{\circ} \mathrm{E}$ (marked C). This cyclonic circulation was associated with anomalous southerly winds through the Mozambique Channel. The region affected by the anomalous

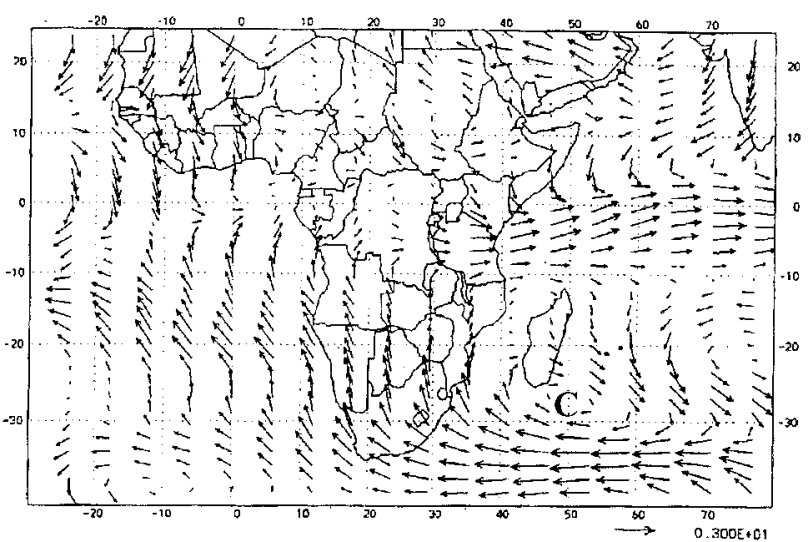

FIG. 5. Wind anomaly for the wet year (1981) minus the dry year (1984) at $700 \mathrm{hPa}(\mathrm{C}=$ cyclonic circulation $)$.

southerly winds extended westward to cover the area $40^{\circ}-10^{\circ} \mathrm{E}$ and between $30^{\circ}$ and $10^{\circ} \mathrm{S}$.

Two distinct rainfall episodes were selected for further study one from each of the selected anomalous years, namely, the persistent wet spells lasting two pentads or more, and the persistent dry spells, also lasting two pentads or more. The vector wind patterns for these wet/dry spells are independently discussed below.

Figure 6 displays an example of the midtropospheric circulation for the wet-spell pentads (a total of six pentads were averaged) during the wet year (1981). Weak westerlies dominated in the EEA region with maximum intensity $\left(4.1 \mathrm{~m} \mathrm{~s}^{-1}\right)$ near the point $6^{\circ} \mathrm{S}, 40^{\circ} \mathrm{E}$. A notable feature was the trough to the south of Madagascar (marked T) with southerlies in the Mozambique Channel. The equatorial westerlies to the south of the equator, together with easterlies to the north of the equator, formed an equatorial vortex with a center near the equator point, $35^{\circ} \mathrm{E}$ (marked $\mathrm{EV}$ ). This equatorial vortex was associated with active convection over the EEA region.

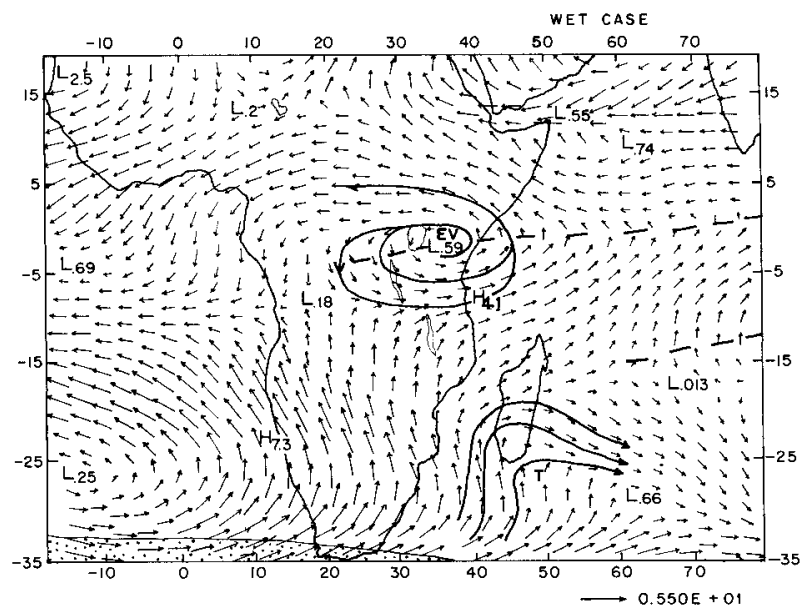

FIG. 6. An example of composite wind vectors at $700 \mathrm{hPa}$ during wet spell pentads. Centers of low/high wind intensity are marked by $\mathrm{L} / \mathrm{H}(\mathrm{EV}=$ equatorial vortex, $\mathrm{T}=$ trough $)$. 


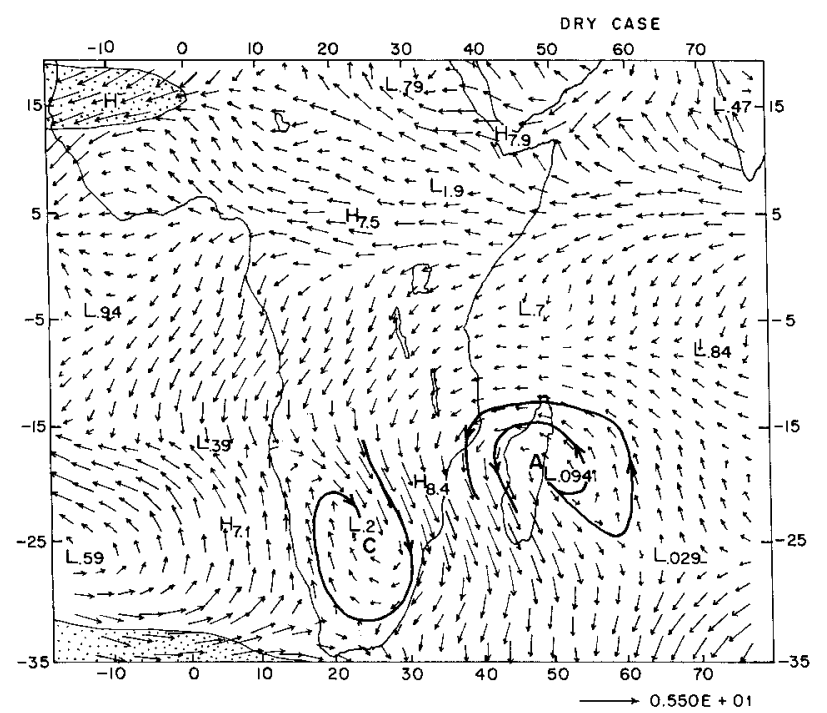

FIG. 7. An example of composite wind vectors at $700 \mathrm{hPa}$ during the dry spell pentads. Centers of low/high wind intensity are marked by $\mathrm{L} / \mathrm{H}(\mathrm{C}=$ cyclonic circulation, $\mathrm{A}=$ anticyclonic circulation $)$.

Figure 7 displays an example of the midtropospheric (700-hPa level) vector wind patterns for the dry pentads (a total of three pentads were averaged). The EEA region was dominated by easterly winds. The most significant feature in the midtropospheric wind flow was the cy-

(a)

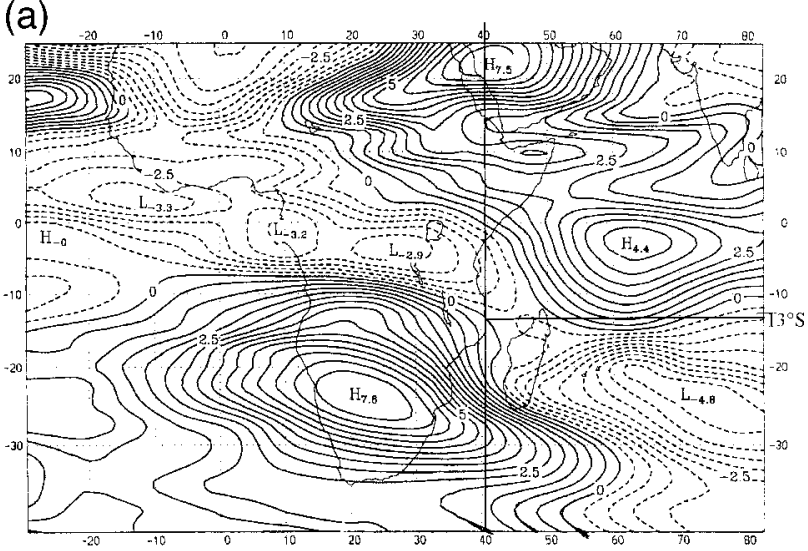

(c)

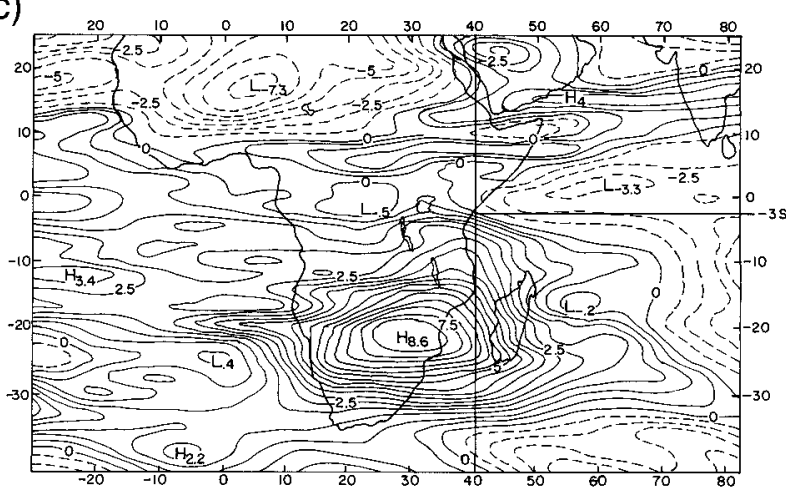

clonic circulation with a center at about $25^{\circ} \mathrm{S}, 25^{\circ} \mathrm{E}$ (marked C) in the composites for the dry pentads. Also, anticyclonic flow was observed over Madagascar (marked A). These cyclonic and anticyclonic circulations were associated with strong northerly winds through the Mozambique Channel. These northerly winds blocked the surge of cold air from the southern extratropics from reaching into the equatorial eastern Africa region.

The southerly meridional wind component at $700-\mathrm{hPa}$ level (Fig. 8a) shows a maximum in the intensity at the point $23^{\circ} \mathrm{S}, 22^{\circ} \mathrm{E}$. This meridional wind component decreases to zero, along $40^{\circ} \mathrm{E}$, at latitude $13^{\circ} \mathrm{S}$ (Fig. 8a) and is more equatorward to the west of this meridian. The meridional wind component penetrated further equatorward at lower levels, reaching $7^{\circ} \mathrm{S}$ at $850 \mathrm{hPa}$ (Fig. 8b) and $3^{\circ} \mathrm{S}$ at 1000 -hPa level (Fig. 8c). This suggests that the meridional southerly flow undercuts the equatorial air mass and this promotes uplift over much of the EEA region. Tyson $(1984,1986)$ has observed a similar undercutting action of southerly meridional flow over South Africa that he noted was an important mechanism in summer rainfall events.

Wet episodes over the EEA region are associated with

1) cyclonic circulation to the southeast of Madagascar with resultant southerlies in the Mozambique Channel and mainland southern Africa between longitudes $10^{\circ}$ and $40^{\circ} \mathrm{E}$; and

(b)

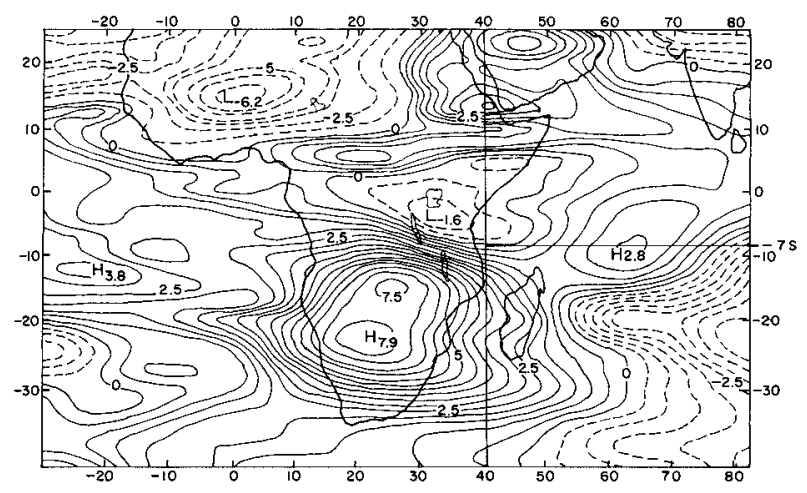

FIG. 8. Examples of composite meridional wind component for the wet spell pentads at (a) $700-\mathrm{hPa}$, (b) $850-\mathrm{hPa}$, and (c) 1000$\mathrm{hPa}$ levels. Continuous contours are for meridional southerly flow while the dashed contours are for northerly flow. Centers of low/ high intensity are marked by $\mathrm{L} / \mathrm{H}$. 


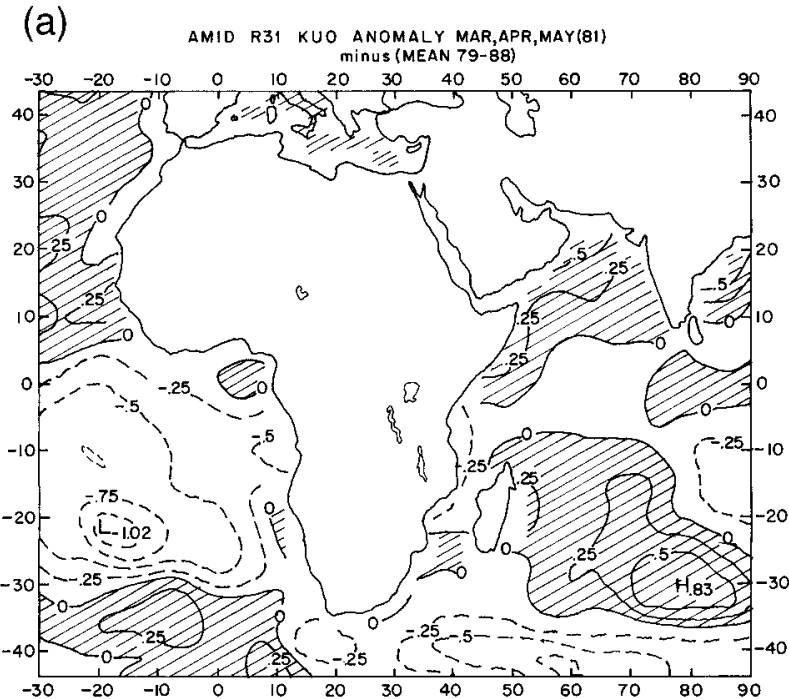

(c)

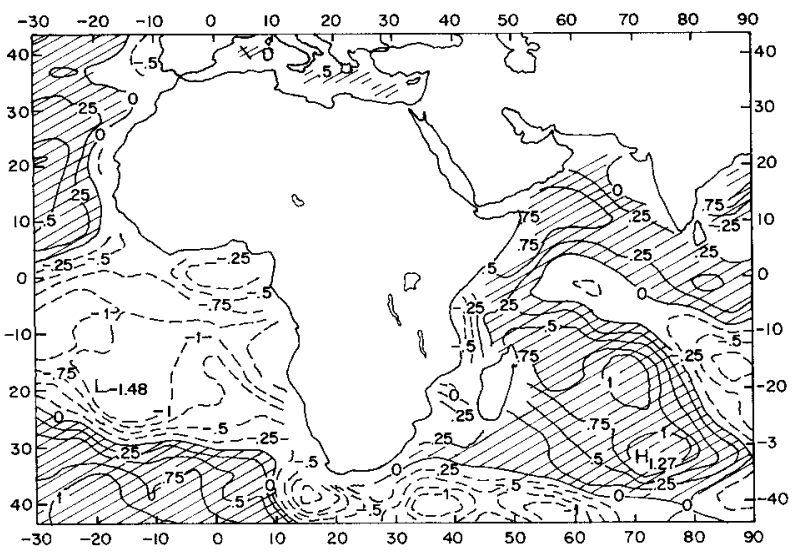

2) westerly winds over the EEA region, extending from $20^{\circ}$ to $80^{\circ} \mathrm{E}$ and over the latitude belt $10^{\circ} \mathrm{S}$ to the equator.

The dry episodes indicate that

1) stronger than normal easterlies occurred over the EEA and the west Indian Ocean, and

2) northerlies were observed in the Mozambique Channel.

The westerlies over the EEA region have originated from the Atlantic Ocean/Congo Basin and as such are moisture laden. Some of this moisture is deposited over EEA as rain. Also, the westerlies have been observed at the sea surface level over the western Indian Ocean during the NHS (Sadler et al. 1987). These westerlies turn into easterlies as part of the EV circulation (Fig. 6) and therefore the easterlies entering into EEA region north of the equator, during this period, are moist and result in enhanced rainfall episodes.

The above illustrations (Figs. 6 and 8) suggest that the marked southerlies during this period may constitute (b)

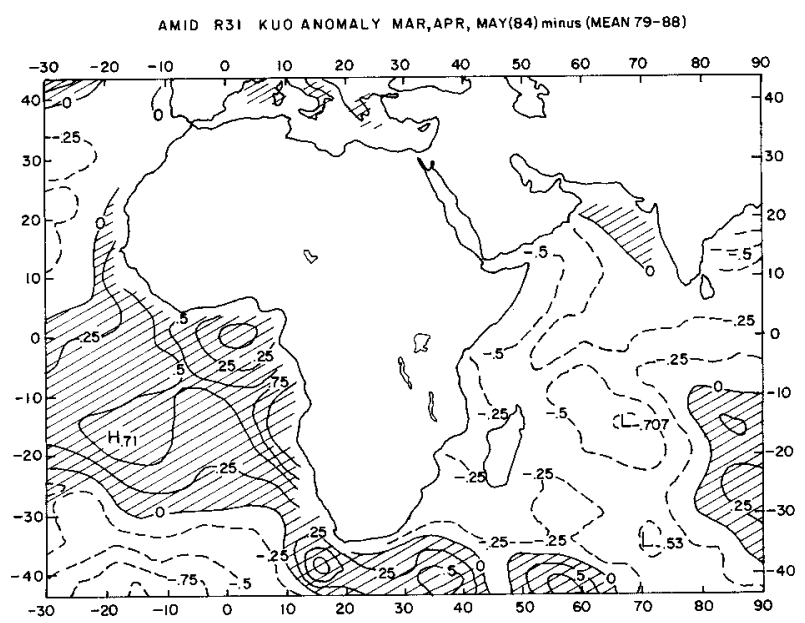

FIG. 9. (a) Seasonal SST anomaly patterns for the wet year (1981). Contour interval is $0.25^{\circ} \mathrm{C}$. Regions of positive anomalies are shaded. (b) Seasonal SST anomaly patterns for the dry year (1984). Contour interval is $0.25^{\circ} \mathrm{C}$. Regions of positive anomalies are shaded. (c) Differences of the seasonal SST between a wet year (1981) and a dry year (1984) during April. The contour interval is $0.25^{\circ} \mathrm{C}$. Regions of positive anomalies are shaded.

an interaction of the extratropics with the equatorial region bringing in a surge of extratropical cold air mass. Also, through conservation of potential vorticity the long northward trajectory must turn eastward. It is apparent that the air having travelled from about $30^{\circ} \mathrm{S}$ is forced to turn eastward in the latitude band $10^{\circ} \mathrm{S}$ and equator. This trajectory modification will be investigated further in a subsequent study.

\section{c. Sea surface temperature anomaly patterns associated with anomalous rainfall events}

Sea surface temperature (SST) anomaly patterns for long rains (March-May) season within the period 197988 have also been investigated here in order to determine the major SST modes that are dominant over the Southwest Indian and Eastern Atlantic oceans during the wet/ dry years over EEA.

Figures 9a,b present the SST anomalies for the March-May period during 1981 and 1984, respectively. During 1981, a wet year, the western Indian Ocean 
(WIO) sector was generally characterized by warm SST anomalies, while the eastern Atlantic Ocean (EAO) had generally dominant cold SST anomalies. During the dry year of 1984, the WIO had cold SST anomalies while the EAO had warm SST anomalies. These SST anomaly patterns are consistent with the observed stronger than normal midtropospheric easterly winds during the dry year (Fig. 4) over the WIO, while the wet year had weaker than normal easterly winds or even westerlies (Fig. 3).

Figure 9c displays the differences between 1981 and 1984 for April SSTs. These differences emphasize more clearly the amplification of the unique patterns observed that dominated the dry/wet scenarios above. It may be concluded that the equatorial westerlies observed over the EEA region and the WIO in the middle levels during the EEA long rains season are consistent with the observed warm/cold SST anomalies over the Indian/Atlantic oceans that encourage westerly flow over equatorial Africa and the WIO. This effect is expected to extend up to the middle levels (near 700-hPa level) due to enhanced moisture availability with convective mixing in the lower troposphere over the warm water pools.

During the wet/dry long rains seasons the wind intensity was weak/strong over EEA and west Indian Ocean regions. These wet and dry cases were closely connected with pools of warm and cool water over the surrounding oceans. The SST anomalies were positive/ negative over WIO for the wet/dry cases. The corresponding SST anomalies over the EAO were also negative/positive, respectively.

\section{Conclusions}

Wet events over EEA region during the NHS are associated with both westerly anomalies over EEA in the latitude belt $10^{\circ} \mathrm{S}$ and the equator, and southerly winds between $30^{\circ}$ and $10^{\circ} \mathrm{S}$. Dry events have generally stronger than normal easterlies in the region $10^{\circ} \mathrm{S}$ and the equator with northerly winds observed in the Mozambique Channel.

These wet/dry events were associated with pools of warm/cool water over the west Indian Ocean and cool/ warm water over the eastern Atlantic Ocean, respectively.

Occurrences of anomalous rainfall in the equatorial east African region may be described (modeled) in terms of the 700-hPa velocity fields.

Acknowledgments. This paper is part of the author's doctoral thesis presented to the University of Nairobi. The author would like to thank Professor Laban A. Ogallo and Dr. Joseph R. Mukabana both of the Department of Meteorology, University of Nairobi, for their continuous guidance and encouragement. The author is deeply indebted to the World Meteorological Organization and the University of Nairobi that offered him fellowships to Australia where the research work reported here was carried out. Special thanks are due to the Bureau of Meteorology (Australia) for providing him with computer resources and acquisition of the ECMWF datasets.

\section{REFERENCES}

Anyamba, E. K., 1983: On the monthly mean lower tropospheric circulation and anomalous circulation during the 1961/62 floods in East Africa. M.S. thesis, Department of Meteorology, University of Nairobi, $240 \mathrm{pp}$.

Bengtsson, L., M. Kanamitsu, P. Kallberg, and S. Uppala, 1982: FGGE 4-dimensional data assimilation at ECMWF. Bull. Amer. Meteor. Soc., 63, 29-43.

Folland, C. K., 1983: Regional scale interannual variability of climate. A northwest European perspective. Meteor. Mag., 112, 163-187.

Johnson, D. H., and H. T. Morth, 1961: Forecasting research in East Africa. East African Meteorological Department Memoirs, Vol. III, No. 9, 57 pp.

LeComte, D., 1985: The year of the African drought. Weatherwise, 38, 8-15.

Matarira, C. H., and M. R. Jury, 1992: Contrasting meteorological structure of intraseasonal wet and dry spells in Zimbabwe. $J$. Climatol., 12, 165-176.

Mukabana, J. R., and R. A. Pielke, 1996: Investigating the influence of synoptic-scale monsoonal winds and mesoscale circulations on diurnal weather patterns over Kenya using a mesoscale numerical model. Mon. Wea. Rev., 124, 224-243.

Nakamura, K., 1968: Equatorial westerlies over East Africa and their climatological significance. Geogr. Rep. 3:43-61, Tokyo Metropolitan University.

Okoola, R. E., 1998: Spatial evolutions of the active convective patterns across the equatorial eastern Africa region during northern hemisphere spring season using OLR records. Meteor. Atmos. Phys., 66, 51-63.

— 1999: A diagnostic study of the Eastern Africa monsoon circulation during the northern hemisphere spring season. Int. J. Climatol., 19, 143-168.

Sadler, J. C., M. A. Lander, A. M. Hori, and L. K. Oda, 1987: Tropical Marine Climatic Atlas. Vol. 1, Indian Ocean and Atlantic Ocean, Dept. of Meteorology, University of Hawaii Rep. UHMET 8701, $51 \mathrm{pp}$.

Tyson, P. D., 1984: The atmospheric modulation of extended wet and dry spells over South Africa, 1958-1978. Int. J. Climatol., 4, 621-635.

- 1986: Climatic Change and Variability over Southern Africa. Oxford University Press, 220 pp.

Ward, M. N., 1992: Provisionally corrected surface wind data, worldwide ocean-atmosphere surface fields and Sahelian rainfall variability. J. Climatol., 5, 454-475. 